UNITED STATES DEPARTMENT OF THE INTERIOR

GEOLOGICAL SURVEY

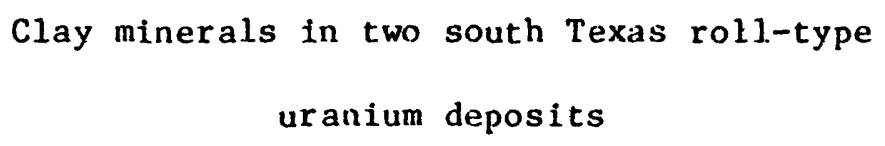

by

R. L. Reynolds, M. B. Goldhaber, P. D. Blackmon,

H. C. Starkey, and N. S. Fishman

Open-File Report $80-838$

1980 


\section{Contents}

\section{$\underline{\text { Page }}$}

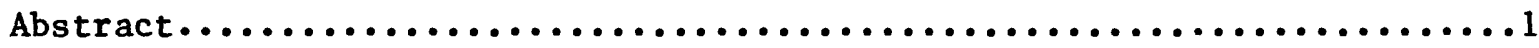

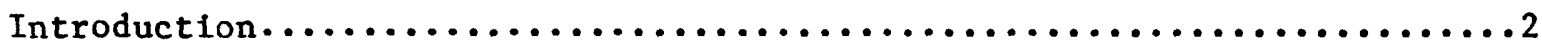

Description of deposits..................................

Sampling and laboratory procedures..........................

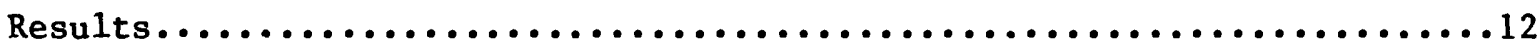

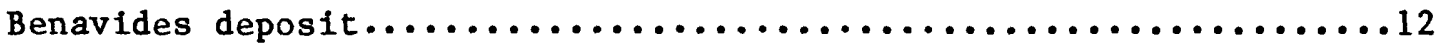

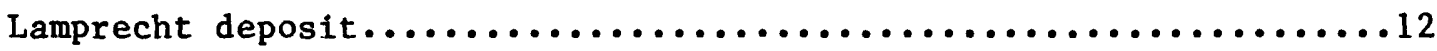

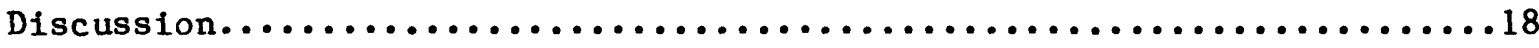

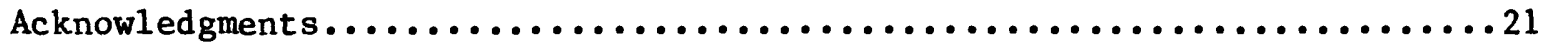

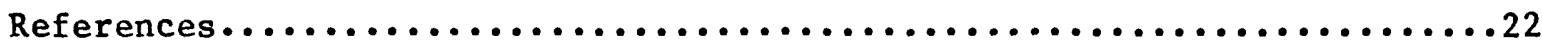


Figure 1. Map of part of the south Texas Coastal Plain.............

2. Plan views of core holes.........................

3. Ratio of montmorillonite to clay-mineral content plotted against clay-size fraction...........................

4. Ratio of illite to clay-mineral content plotted against

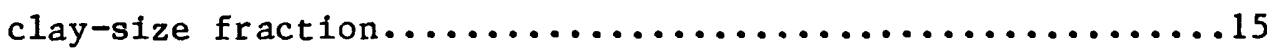

5. $\mathrm{U}_{3} \mathrm{O}_{8}$ content plotted against ratio of montmorillonite to clay-mineral content............................

Tables

Table 1. Summary of clay-mineral data from the Benavides deposit......10

2. Summary of clay-mineral data from the Lamprecht deposit.......11

3. Average proportions of montmorillonite and illite to clay-mineral population........................ 


\title{
Clay minerals in two south Texas roll-type \\ uranium deposits
}

by

R. L. Reynolds, M. B. Goldhaber, P. D. Blackmon, H. C. Starkey, and N. S. Fishman

\begin{abstract}
Semiquantitative X-ray diffraction techniques have been used to identify and analyze distribution patterns of clay minerals in the host rocks for two south Texas roll-type uranium deposits. In sandstone and mudstone of the Benavides deposit, emplaced in the Miocene Catahoula Tuff, montmorillonite is the dominant clay mineral, and illite is present in small amounts. Claymineral distribution in the Lamprecht deposit, in the Miocene Oakville Sandstone, is controlled primarily by lithology: Montmorillonite is the dominant clay mineral in sandstone, whereas illite is the dominant clay in mudstone. Kaolinite is present in most samples from the Lamprecht deposit but commonly in small amounts (less than 10 percent of the total clays). Chlorite, in trace amounts, was identified in only two of 62 samples from the Lamprecht deposit. Clay-mineral distribution in the Benavides and Lamprecht deposits is not related to processes of mineralization. In contrast, clay minerals (primarily chlorite) have been concentrated in mineralized rock of some roll-type and tabular uranium deposits in Wyoming and New Mexico. Organic matter is present in host rocks for deposits having such concentrations and may have influenced clay-mineral authigenesis. The lack of claymineral zonation relative to ore zones of the Benavides and Lamprecht deposits may be due in part to the lack of organic matter in the host rocks.
\end{abstract}




\section{Introduction}

Authigenesis of clay minerals in sedimentary rock hosts for uranium deposits may be controlled not only by the composition and reactivity of detrital constituents, but also by $\mathrm{pH}$ and redox conditions and by activities of lons in ground-water solutions. The abundance and distribution of clay minerals across uranium deposits, therefore, may reflect, in part, chemical conditions of uranium deposition.

Clay-mineral assemblages associated with uranium deposits have been most thoroughly studied in samples from the Jurassic Morrison Formation in the area of the Grants mineral belt, New Mexico (Granger, 1962; Brookins, 1975; Adams and others, 1978). Granger found that montmorillonite, derived probably from alteration of detrital volcanic glass, is the dominant clay mineral in the sandstones and mudstones of the Morrison on the southern margin of the San Juan Basin. Kaolinite was observed in two associations of different ages: (1) In sandstone where overlain directly by the Cretaceous Dakota Sandstone bearing abundant organic matter; and (2) in scattered nests throughout much of the Morrison. Granger concluded that kaolinite in the former occurrence may in some way be related to the formation of uranium deposits, whereas kaolinite in the latter form postdated mineralization. Illite in minor amounts was present in some of the samples that Granger analyzed. Especially significant are Granger's observations that, in primary ore zones of the Ambrosia Lake area, chlorite concentrations correlate roughly with concentrations of uranium and organic carbon, and that chlorite formed from montmorillonite. Similarly, Brookins (1975) noted the enrichment of vanadiferous chlorite relative to montmorillonite in primary ore zones along much of the Grants mineral belt. He suggested that because of the close spatial relationship of chlorite with organic carbon-rich ore bodies, the 
chlorite formed during introduction of humic acids into the host rock. Kaolinite and illite are also present in ore samples analyzed by Brookins but bear no apparent relationship to mineralization. Adams and others (1978) also reported a close association between authigenic clay (mixed-layer illitemontmorillonite) and uranium in ore-bearing carbonaceous lenses (but did not detect chlorite) in the host sandstone for the Jackpile-Paguate ore bodies of the Grants mineral belt. Additionally, concentrations of vanadium-bearing clays (predominantly chlorite) and mixed-layer clays (chlorite-montmorillonite and illite-montmorillonite) have been found in some vanadium-uranium ore zones In the Morrison Formation on the Colorado Plateau (Garrels and others, 1959). Concentrations of chlorite in ore from roll-type deposits in Eocene sandstones of the Crooks Gap and Gas Hills uranium districts have been reported by Files (1970). Such concentrations occur but are rare in ore samples from the Eocene Wind River Formation in the Shirley Basin (Files, 1970). Kaolinite, montmorillonite, and mixed-layer clays (montmorilloniteillite and montmorillonite-illite-chlorite) are present also in samples from host rock in the Crooks Gap, Gas Hills, and Shirley Basin areas but are not genetically related to mineralization (Files, 1970).

Anomalous occurrences of chlorite associated with uranium deposits in south Texas have not yet been reported. Dickinson and Sullivan (1976), however, noted that montmorillonite was absent in samples of ore and present in unmineralized samples from an oxidized uranium deposit in the Eocene Whitsett Formation, Karnes County, Tex. In contrast, Daniels and others (1977), using X-ray diffraction data and data from resistivity and inducedpolarization surveys, reported an enrichment of montmorillonite in the ore zone of a roll-type deposit in the Miocene Oakville Sandstone in Live Oak County, Tex. 
Detailed study of the clay-mineral assemblages in rol1-type deposits may lead to better understanding of the genesis of these deposits. This paper presents data on and compares the abundance and distribution of clay minerals in host rocks for two roll-type deposits in south Texas in order to broaden the data base for clay-mineral assemblages associated with these kinds of deposits. Our studies show that, in the two deposits, clay minerals are not concentrated in ore, and so their presence is apparently unrelated to mineralization processes. Although negative in this sense, the results of our studies are nevertheless important in light of the zonation of clay minerals recognized elsewhere.

\section{Description of deposits}

The two deposits studied are in south Texas, the Benavides deposit near Bruni in Webb County, and the Lamprecht deposit near Ray Point in Live Oak County (fig. 1). The geologic setting, mineralogy, geochemistry, and genesis of the Benavides deposit have been discussed previously (Goldhaber and Reynolds, 1977; Reynolds and Goldhaber, 1978; Goldhaber and others, 1978; and Granger and Warren, 1974). Similar aspects of the Lamprecht deposit were described by Goldhaber and others (1979), and Daniels and others (1977). A brief summary of the geologic setting and mineralogy of the deposits is given below.

The Benavides deposit occurs in a channel-fill sandstone of the Miocene Catahoula Tuff, a unit that contains locally abundant volcanically derived detritus including air-fall ash. The deposit formed from continuous downdip ingress of oxygenated uranium-bearing solutions into sulfidized (reduced) rock. This process resulted in alteration of a tongue-shaped body of rock (the altered or oxidized tongue) and concentration of uranium at and in front 


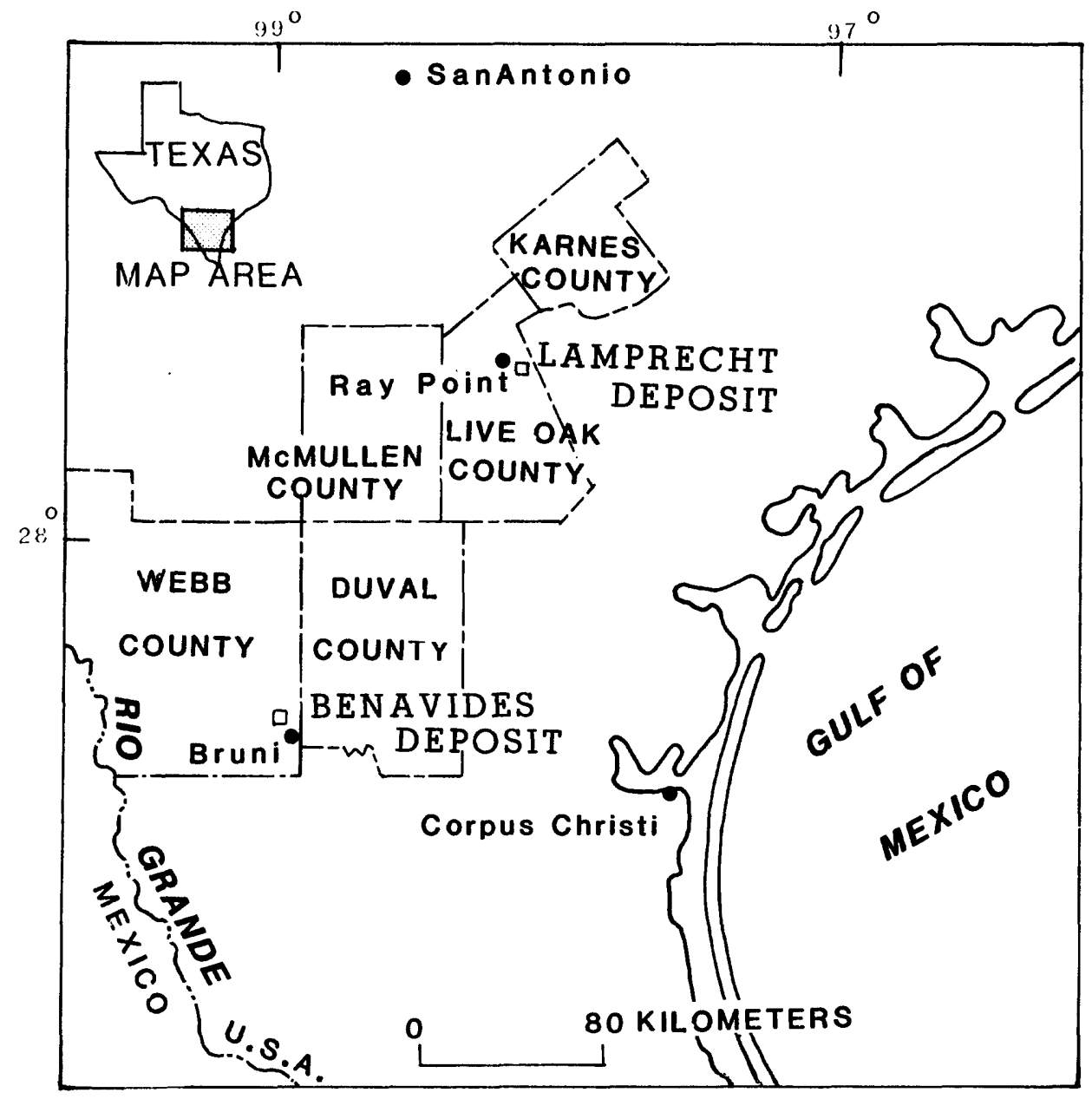

Figure 1.-Map of part of the south Texas Coastal-Plain showing locations of the Benavides and Lamprecht deposits. 
of the oxidation-reduction interface. Pre-mineralization sulfidization of the host rock was caused by $\mathrm{H}_{2} \mathrm{~S}$-bearing solutions introduced along a normal fault that is $1.6 \mathrm{~km}$ downdip from the ore roll.

The Lamprecht deposit occurs in fluvial sandstone of the Miocene Oakville Sandstone which overlies the Catahoula. The roll geometry and distribution of elements in the Lamprecht are similar to those of the Benavides and indicate a similar mode of formation. As with the Benavides deposit, there is a close spatial relationship of the ore roll to a normal fault; it is suspected, but not firmly established, that some of the recognizable preore iron disulfide minerals were engendered by $\mathrm{H}_{2} \mathrm{~S}$ introduced from this fault. The Lamprecht deposit differs most noticeably from the Benavides in that host rock for the Lamprecht has been resulfidized (rereduced) so that the altered tongue now contains iron disulfide minerals.

Unlike the host rocks for deposits in the Jurassic Morrison Formation in the Grants mineral belt and in the Tertiary sandstones of the Wyoming basins studied by Files (1970), host rocks for the Benavides and Lamprecht deposits are devoid of carbonaceous matter.

\section{Sampling and laboratory procedures}

Samples from the Benavides and Lamprecht deposits, provided by Wyoming Mineral Corp., were obtained from suites of cores drilled along fences that trend across the respective roll fronts (fig 2). Horizontal sample coverage for the Benavides deposit was from $1.0 \mathrm{~km}$ updip from the nose of the roll front to $0.7 \mathrm{~km}$ in the downdip direction in front of the rol1; for the Lamprecht deposit, from $0.9 \mathrm{~km}$ updip to $0.4 \mathrm{~km}$ downdip from the roll front. Between 10 and $13 \mathrm{~m}$ of sample from each core hole were available for study. 

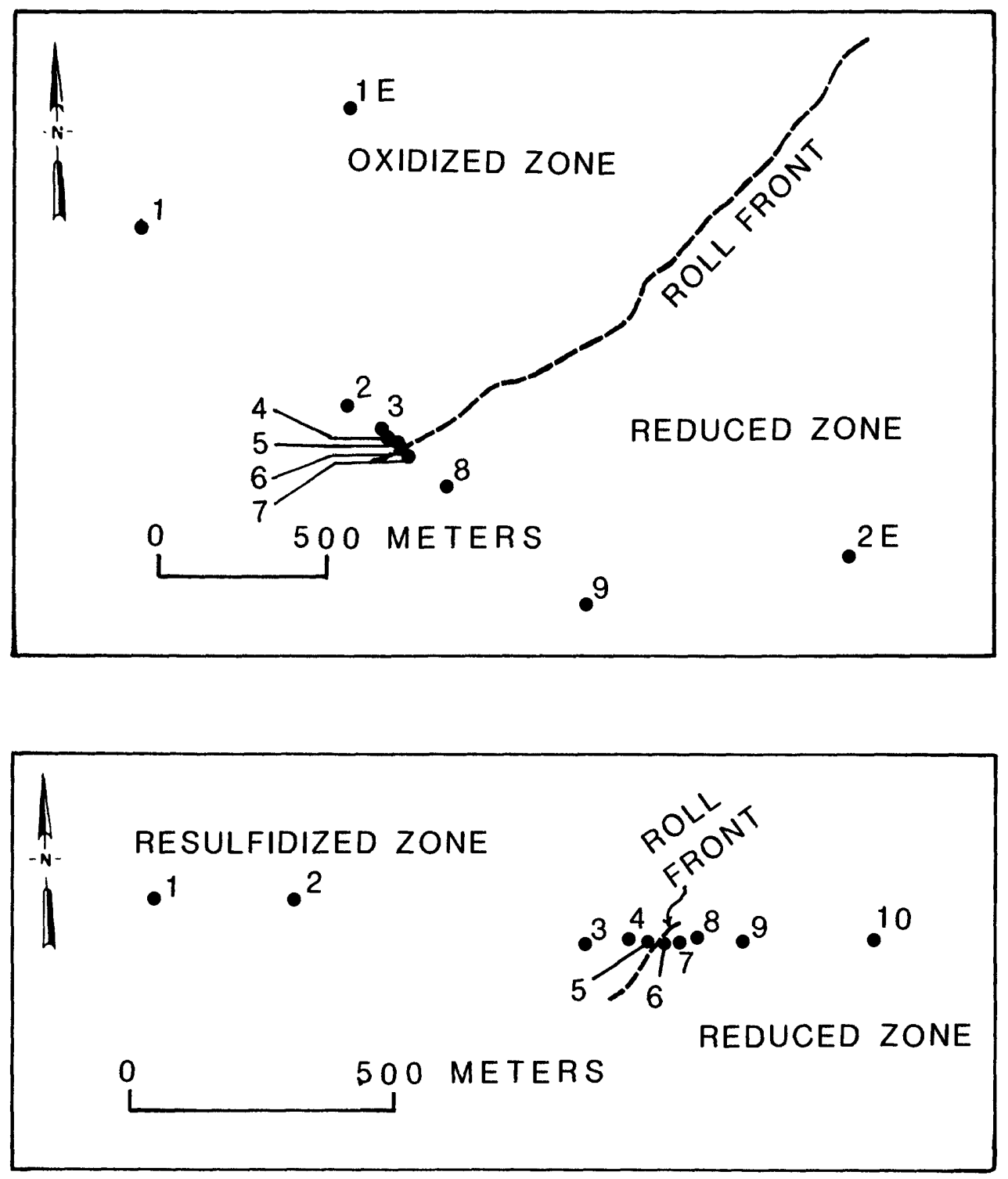

Figure 2.- Plan views of core holes in relation to roll fronts. A. Benavides deposit.

B. Lamprecht deposit. 
Thirty samples from the Benavides deposit and 62 from the Lamprecht were analyzed to determine clay-mineral content. Except for samples from cores 9 and 10 in the Lamprecht deposit, a portion of each sample was weighed and analyzed for grain-size distribution in the silt- and clay-size fraction, and additionally in the sand-size fraction for samples from the Lamprecht. The sand was separated from the bulk samples of the Lamprecht cores by wet sieving through a 230-mesh sieve, after 10 minutes of ultrasonic treatment in distilled water. (The sand-size fraction had been removed from samples of the Benavides cores prior to this study). Silt and clay were separated by centrifugation. A part of the clay-size (less than $2 \mu \mathrm{m}$ ) fraction, separated by centrifugation from each of the bulk samples, was orlented on porous t1les. A part of each whole sample and of the different size fractions from the Lamprecht samples, and a part of the silt- and clay-size fractions from the Benavides samples were analyzed by $\mathrm{X}$-ray diffraction using $\mathrm{Cu}-\mathrm{K}_{\alpha}$ radiation in an X-ray diffractometer equipped with a focusing monochromator to minimize effects of iron fluorescence. Clay-mineral identifications were based on diffraction-peak behavior after each of the following treatments of the oriented samples: air-dried; ethylene glycol saturation for 4 hours by a vapor pressure method; heating at $400^{\circ} \mathrm{C}$ for one-half hour; and heating at $550^{\circ} \mathrm{C}$ for one-half hour.

Standard patterns were derived from X-ray diffraction analysis of synthetic mixtures contalning known weighed amounts of the mineral species present in the core samples. Using these patterns, abundances of clay minerals were estimated in trace amounts, indicating an abundance of less than 5 percent, in amounts less than one part in 10 (about 5 to less than 10 percent), and, for greater amounts, in parts of 10 . For purpose of tabulating and analyzing the data, we converted the estimated abundances to approximate 
weight percentages. For example, we used 7 percent to approximate amounts given as "less than one part in 10 ", and 2.5 percent to approximate "trace" amounts.

The data are presented (tables 1 and 2) for each sample as a ratio in weight percent of a specific clay mineral to the total clay-mineral content in the clay-size fraction. These ratios do not reflect the lack of precision of the semiquantitative X-ray diffraction determinations. Such treatment, however, is necessary in order to account numerically for trace amounts and those given as less than 10 percent. This method of analysis does not introduce bias into the results, nor would it have masked significant zonation patterns, had they been present.

Minerals other than clays detected in the $<2 \mu \mathrm{m}$ fraction (not shown in tables 1 and 2) included quartz, feldspar, calcite, anatase, clinoptilolite and pyrite in the Catahoula Tuff, and quartz, feldspar, calcite, anatase, clinoptilolite, opaline silica, and pyrite in the Oakville Sandstone.

Most clay minerals in the sand- and silt-size fractions probably occur in clay aggregates that were not separated by the fractionation procedure, but some clays are probably present also in altered volcanic rock fragments. Although the dominance of constituents other than clay minerals in the sandand silt-size fractions masked to a great extent the presence of clays, no significant differences in the types of clay minerals present and their relative distribution were detected in the different size fractions of individual samples. The discussion that follows is based on results from the clay-size fraction except where noted. 
Table 1.--Summary of clay-mineral data ( $<2 \mu \mathrm{m}$-size fraction) from the Benavides deposit

[CMT, clay minerals in clay-size fraction; --, not detected]

\begin{tabular}{|c|c|c|c|c|c|c|}
\hline \multirow{2}{*}{$\begin{array}{l}\text { Core- } \\
\text { sample }\end{array}$} & \multirow{2}{*}{$\begin{array}{l}\text { Depth } \\
\text { (meters) }\end{array}$} & \multirow{2}{*}{$\begin{array}{l}\text { Lithic } \\
\text { type }\end{array}$} & \multirow{2}{*}{$\begin{array}{c}\text { Geochemical } \\
\text { zone }\end{array}$} & \multirow[t]{2}{*}{ CMT } & \multirow[t]{2}{*}{$\begin{array}{c}\text { Montmorillionite/ } \\
\text { CMT }\end{array}$} & \multirow[t]{2}{*}{$\begin{array}{c}\text { Illite/ } \\
\text { CMT }\end{array}$} \\
\hline & & & & & & \\
\hline $1-1$ & $28.0-32.9$ & Sandstone & Altered tongue & 72.0 & 90 & 10 \\
\hline $1 E-1$ & $34.1-40.2$ & $--\mathrm{do}--$ & -- do-- & 54.5 & 83 & 5 \\
\hline 2 & $40.2-42.7$ & -- do-- & --do-- & 67.5 & 96 & 4 \\
\hline 3 & $42.7-44.2$ & Muds tone & $--\mathrm{do}--$ & 67.5 & 96 & 4 \\
\hline $2-1$ & $30.8-35.1$ & Sandstone & $--\mathrm{do}--$ & 67.5 & 96 & 4 \\
\hline 2 & $35.1-37.8$ & $--\mathrm{do}--$ & -- do-- & 62.5 & 96 & 4 \\
\hline 3 & $38 \cdot 7-41 \cdot 1$ & --do-- & --do-- & 62.5 & 96 & 4 \\
\hline 4 & $41.8-43.0$ & Mudstone & -- do-- & 72.5 & 90 & 10 \\
\hline 5 & $43 \cdot 0-43 \cdot 6$ & -- do-- & Reduced barren & 72.5 & 90 & 10 \\
\hline 6 & $43.6-44.8$ & Sands tone & -- do-- & 67.5 & 96 & 4 \\
\hline $3-1$ & $32.0-34.7$ & -- do-- & -- do-- & 72.0 & 90 & 10 \\
\hline 2 & $35.4-36.6$ & - -do-- & -- do-- & 62.0 & 89 & 11 \\
\hline 3 & $36 \cdot 9-38 \cdot 1$ & --do-- & Altered tongue & 67.5 & 96 & 4 \\
\hline 4 & $38.1-42.4$ & -- do-- & -- do-- & 67.5 & 96 & 4 \\
\hline 5 & $42.4-43.9$ & Mudstone & -- do-- & 72.5 & 97 & 3 \\
\hline 6 & $43.9-45.1$ & --do-- & Reduced barren & 67.5 & 96 & 4 \\
\hline $6-1$ & $34.4-36.9$ & Sandstone & -- do-- & 67.5 & 96 & 4 \\
\hline 2 & $36.9-38.1$ & -- do-- & Mineralized & 72.0 & 90 & 10 \\
\hline 3 & $38 \cdot 1-39 \cdot 3$ & -- do-- & -- do-- & 57.5 & 96 & 4 \\
\hline 4 & $39.3-40.8$ & --do-- & -- do-- & 67.5 & 96 & 4 \\
\hline 5 & $40.8-41.8$ & -- do-- & -- do-- & 67.5 & 96 & 4 \\
\hline 6 & $41.8-43.4$ & $--d o--$ & Reduced barren & 67.5 & 96 & 4 \\
\hline $8-1$ & $32.0-36.9$ & --do-- & --do-- & 57.5 & 96 & 4 \\
\hline 2 & $36.9-38.4$ & Mudstone & -- do-- & 60.0 & 92 & 4 \\
\hline 3 & $38.4-39.6$ & Sandstone & -- do-- & 52.5 & 95 & 5 \\
\hline 4 & $42 \cdot 2-44 \cdot 7$ & -- do-m & Mineralized & 55.0 & 100 & -- \\
\hline 5 & $44.7-48.2$ & Mudstone & Reduced barren & 72.0 & 90 & 10 \\
\hline $9-1$ & $39.0-44.2$ & Sands tone & Reduced barren & 72.0 & 90 & 10 \\
\hline 2 & $44 \cdot 2-45 \cdot 7$ & Mudstone & -- do-- & 75.0 & 87 & 13 \\
\hline 3 & $45.7-48.8$ & $--\mathrm{do--}$ & $--\mathrm{do}--$ & 62.0 & 89 & 11 \\
\hline
\end{tabular}


Table 2. --Summary of clay-mineral data $(<2$ ym-slze fraction) from the Lamprecht deposit

(CMT, clay minerals in clay-size fraction; *, includes trace amount of chlorite; -- , not detected]

\begin{tabular}{|c|c|c|c|c|c|c|c|}
\hline \multirow{2}{*}{$\begin{array}{l}\text { Core- } \\
\text { sample }\end{array}$} & \multirow{2}{*}{$\begin{array}{c}\text { Depth } \\
\text { (meters) }\end{array}$} & \multirow{2}{*}{$\begin{array}{l}\text { Lithic } \\
\text { type }\end{array}$} & \multirow{2}{*}{$\begin{array}{l}\text { Geochemical } \\
\text { zone }\end{array}$} & \multirow[t]{2}{*}{$\underline{\mathrm{CMT}}$} & $\begin{array}{c}\text { Montmorillionite/ } \\
\mathrm{CMr}\end{array}$ & \multirow{2}{*}{$\begin{array}{c}\text { Illited } \\
\mathrm{CMT}\end{array}$} & \multirow[t]{2}{*}{$\begin{array}{c}\text { Raolinite/ } \\
\text { CMT }\end{array}$} \\
\hline & & & & & Weight $p$ & & \\
\hline $\begin{array}{r}1-20 \\
21\end{array}$ & $\begin{array}{l}65.2-66.1 \\
66.1-66.8\end{array}$ & $\begin{array}{l}\text { Sandstone } \\
\text { Mudstone }\end{array}$ & $\begin{array}{l}\text { Reduced barren } \\
\text { Altered tongue }\end{array}$ & $\begin{array}{l}77.5 \\
85.0\end{array}$ & $\begin{array}{l}77 \\
23\end{array}$ & $\begin{array}{l}19 \\
77\end{array}$ & $\begin{array}{r}3 \\
--\end{array}$ \\
\hline $\begin{array}{r}2-4 \\
7 \\
8 \\
11 \\
12\end{array}$ & $\begin{array}{l}66.8-68.6 \\
70.1-70.7 \\
70.7-71.3 \\
72.5-73.2 \\
82.3-82.9\end{array}$ & $\begin{array}{l}\text {-do-- } \\
\text {--do-- } \\
\text {-do-- } \\
\text {--do-- } \\
\text {-do-- }\end{array}$ & $\begin{array}{l}\text { Reduced barren } \\
\text { Altered tongue } \\
\text {--do-- } \\
\text {--do-- } \\
\text { Reduced barren }\end{array}$ & $\begin{array}{l}85.0 \\
87.5^{\star} \\
80.0 \\
80.0 \\
80.0\end{array}$ & $\begin{array}{l}35 \\
34 \\
31 \\
31 \\
25\end{array}$ & $\begin{array}{l}65 \\
63 \\
69 \\
69 \\
75\end{array}$ & $\begin{array}{l}- \\
- \\
- \\
-\end{array}$ \\
\hline $\begin{array}{r}3-15 \\
19 \\
24 \\
28 \\
29 \\
30\end{array}$ & $\begin{array}{l}65.8-66.4 \\
68.3-68.9 \\
71.3-71.9 \\
74.4-75.2 \\
75.2-75.6 \\
75.6-75.9\end{array}$ & $\begin{array}{l}\text { Sandstone } \\
\text {-do-- } \\
\text {--do-- } \\
\text {-do-- } \\
\text { Mudstone } \\
\text {-do-- }\end{array}$ & $\begin{array}{l}\text { Mineralized } \\
\text { Altered tongue } \\
\text {--do-- } \\
\text {--do-- } \\
\text { Mineralized } \\
\text {--do-- }\end{array}$ & $\begin{array}{l}87.0 \\
82.0 \\
75.0 \\
76.5 \\
80.0 \\
82.0\end{array}$ & $\begin{array}{r}75 \\
91 \\
100 \\
97 \\
31 \\
9\end{array}$ & $\begin{array}{r}8 \\
9 \\
- \\
-- \\
69 \\
91\end{array}$ & $\begin{array}{l}17 \\
-- \\
-- \\
-\end{array}$ \\
\hline $\begin{array}{c}4-2 \\
6 \\
12 \\
17 \\
22 \\
25 \\
26 \\
27\end{array}$ & $\begin{array}{l}63.4-64.0 \\
65.7-66.3 \\
69.3-70.0 \\
72.2-72.8 \\
75.1-75.7 \\
77.1-77.4 \\
77.4-77.7 \\
77.7-78.3\end{array}$ & $\begin{array}{l}\text { Sandstone } \\
\text { Mudstone } \\
\text { Sandstone } \\
\text {-do-- } \\
\text {--do-- } \\
\text {--do-- } \\
\text { Mudstone } \\
\text {--do-- }\end{array}$ & $\begin{array}{l}\text { Reduced barren } \\
\text {--do-- } \\
\text { Mineralized } \\
\text { Altered tongue } \\
\text {--do-- } \\
\text {--do-- } \\
\text { Mineralized } \\
\text { Reduced barren }\end{array}$ & $\begin{array}{l}77.0 \\
77.0 \\
82.0 \\
74.5 \\
90.0 \\
57.5 * \\
85.0 \\
80.0\end{array}$ & $\begin{array}{l}71 \\
45 \\
67 \\
87 \\
83 \\
96 \\
24 \\
13\end{array}$ & $\begin{array}{l}19 \\
45 \\
24 \\
10 \\
17 \\
76 \\
87\end{array}$ & $\begin{array}{r}10 \\
10 \\
9 \\
3 \\
-- \\
-- \\
-- \\
-\end{array}$ \\
\hline $\begin{array}{r}5-2 \\
5 \\
8 \\
10 \\
13 \\
15 \\
20 \\
22\end{array}$ & $\begin{array}{l}67.1-67.7 \\
68.9-69.5 \\
70.7-71.3 \\
71.6-72.2 \\
73.5-74.1 \\
74.7-75.3 \\
77.4-77.7 \\
78.0-78.6\end{array}$ & $\begin{array}{l}\text {--do-- } \\
\text { Sandstone } \\
\text {--do-- } \\
\text {-do-- } \\
\text {--do-- } \\
\text {-do-- } \\
\text {--do-- } \\
\text {-do-- }\end{array}$ & $\begin{array}{l}\text {--do-- } \\
\text {--do-- } \\
\text { Mineralized } \\
\text {--do-- } \\
\text { Altered tongue } \\
\text {--do-- } \\
\text { Reduced barren } \\
\text { Mineralized }\end{array}$ & $\begin{array}{l}72.0 \\
77.0 \\
69.5 \\
69.0 \\
74.5 \\
62.0 \\
67.0 \\
80.0\end{array}$ & $\begin{array}{l}42 \\
71 \\
86 \\
80 \\
87 \\
89 \\
90 \\
81\end{array}$ & $\begin{array}{l}49 \\
10 \\
10 \\
10 \\
10 \\
11 \\
10 \\
19\end{array}$ & $\begin{array}{r}10 \\
19 \\
4 \\
10 \\
3 \\
- \\
-- \\
-\end{array}$ \\
\hline $\begin{array}{c}6-4 \\
7 \\
10 \\
15 \\
18 \\
19\end{array}$ & $\begin{array}{l}69.2-70.0 \\
71.0-71.6 \\
72.8-73.5 \\
75.9-76.5 \\
77.9-78.6 \\
78.6-79.2\end{array}$ & $\begin{array}{l}\text {-do-- } \\
\text {-do-- } \\
\text {--do-- } \\
\text {-do-- } \\
\text {--do-- } \\
\text {-do-- }\end{array}$ & $\begin{array}{l}\text { Reduced barren } \\
\text { Mineralized } \\
\text {--do-- } \\
\text {--do-- } \\
\text {--do-- } \\
\text {--do-- }\end{array}$ & $\begin{array}{l}82.0 \\
32.5 \\
62.5 \\
60.0 \\
60.0 \\
67.5\end{array}$ & $\begin{array}{l}61 \\
62 \\
72 \\
75 \\
74 \\
78\end{array}$ & $\begin{array}{l}30 \\
30 \\
24 \\
25 \\
22 \\
17\end{array}$ & $\begin{array}{r}9 \\
8 \\
4 \\
- \\
4 \\
5\end{array}$ \\
\hline $\begin{array}{c}7-5 \\
8 \\
11 \\
15 \\
19 \\
21 \\
22\end{array}$ & $\begin{array}{l}69.2-69.8 \\
71.0-71.6 \\
73.5-74.1 \\
75.6-76.2 \\
78.6-79.2 \\
79.9-80.5 \\
80.5-81.2\end{array}$ & $\begin{array}{l}\text {--do-- } \\
\text {--do-- } \\
\text {--do-- } \\
\text {--do-- } \\
\text {--do-- } \\
\text {--do-- } \\
\text {--do-- }\end{array}$ & $\begin{array}{l}\text { Reduced barren } \\
\text { Mineralized } \\
\text {--do-- } \\
\text {--do-- } \\
\text {--do-- } \\
\text {--do-- } \\
\text {--do-- }\end{array}$ & $\begin{array}{l}72.0 \\
77.0 \\
74.5 \\
50.0 \\
57.5 \\
47.0 \\
75.0\end{array}$ & $\begin{array}{l}62 \\
71 \\
87 \\
90 \\
96 \\
85 \\
87\end{array}$ & $\begin{array}{r}28 \\
20 \\
10 \\
5 \\
4 \\
15 \\
13\end{array}$ & $\begin{array}{r}10 \\
9 \\
3 \\
5 \\
-- \\
- \\
--\end{array}$ \\
\hline $\begin{array}{r}8-2 \\
6 \\
9 \\
11 \\
13 \\
15 \\
19 \\
22 \\
24\end{array}$ & $\begin{array}{l}68.0-68.1 \\
70.3-70.7 \\
71.9-73.5 \\
73.3-73.8 \\
75.0-75.7 \\
76.4-77.1 \\
78.6-79.1 \\
80.3-80.9 \\
81.4-81.8\end{array}$ & $\begin{array}{l}\text {--do-- } \\
\text {--do-- } \\
\text {--do-- } \\
\text {--do-- } \\
\text {-do-- } \\
\text {--do-- } \\
\text {-do-- } \\
\text {--do-- } \\
\text {--do-- }\end{array}$ & $\begin{array}{l}\text { Reduced barren } \\
\text {--do-- } \\
\text {--do-- } \\
\text { Mineralized } \\
\text {--do-- } \\
\text {--do-- } \\
\text {--do-- } \\
\text { Reduced barren } \\
\text {--do-- }\end{array}$ & $\begin{array}{l}72.5 \\
74.5 \\
89.0 \\
79.0 \\
76.5 \\
65.0 \\
54.5 \\
65.0 \\
55.0\end{array}$ & $\begin{array}{r}83 \\
87 \\
84 \\
82 \\
96 \\
100 \\
83 \\
100 \\
100\end{array}$ & $\begin{array}{r}3 \\
3 \\
8 \\
9 \\
- \\
-13 \\
- \\
--\end{array}$ & $\begin{array}{r}14 \\
9 \\
8 \\
9 \\
4 \\
-- \\
-4 \\
--\end{array}$ \\
\hline $\begin{array}{r}9-7 \\
10 \\
14 \\
18 \\
22 \\
25\end{array}$ & $\begin{array}{l}70.1-70.9 \\
71.9-72.8 \\
75.3-75.9 \\
78.3-78.9 \\
80.9-81.4 \\
82.9-83.5\end{array}$ & $\begin{array}{l}\text {--do-- } \\
\text {--do-- } \\
\text {--do-- } \\
\text {--do-- } \\
\text {--do-- } \\
\text {-do-- }\end{array}$ & $\begin{array}{l}\text {--do-- } \\
\text {--do-- } \\
\text {--do-- } \\
\text {--do-- } \\
\text {--do-- } \\
\text {--do-- }\end{array}$ & $\begin{array}{l}64.0 \\
77.5 \\
82.0 \\
77.5 \\
60.0 \\
79.5\end{array}$ & $\begin{array}{l}78 \\
77 \\
73 \\
84 \\
92 \\
88\end{array}$ & $\begin{array}{r}11 \\
20 \\
18 \\
13 \\
4 \\
9\end{array}$ & $\begin{array}{r}11 \\
3 \\
9 \\
3 \\
4 \\
3\end{array}$ \\
\hline $\begin{array}{r}10-9 \\
13 \\
17 \\
20 \\
22\end{array}$ & $\begin{array}{l}80.1-80.8 \\
82.9-83.4 \\
85.0-85.6 \\
87.5-88.1 \\
90.5-90.9\end{array}$ & $\begin{array}{l}\text {--do-- } \\
\text {--do-- } \\
\text {--do-- } \\
-- \text { do-- } \\
-- \text { do-- }\end{array}$ & $\begin{array}{l}\text {--do-- } \\
\text {--do-- } \\
\text {--do-- } \\
\text {--do-- } \\
\text {--do-- }\end{array}$ & $\begin{array}{l}72.5 \\
72.5 \\
69.5 \\
64.5 \\
77.5\end{array}$ & $\begin{array}{l}83 \\
83 \\
86 \\
85 \\
84\end{array}$ & $\begin{array}{l}14 \\
14 \\
10 \\
11 \\
13\end{array}$ & $\begin{array}{l}3 \\
3 \\
4 \\
4 \\
3\end{array}$ \\
\hline
\end{tabular}




\section{Results}

\section{Benavides deposit}

Montmorillonite and illite are the only clay minerals detected in samples of the Catahoula Tuff (table 1). Montmorillonite is the dominant clay and is present in nearly uniform amounts composing commonly 90 percent or greater of the clay-mineral population. Montmorillonite content does not vary in relation to geochemical zone (ore, reduced barren rock, and altered tongue). Nor does the proportion of montmorillonite to total clay content vary with lithic type; it is also uniformly high in mudstones. Most samples (23 of 30) contain montmorillonite with interlayers of illite, but the presence and amount of 111ite interlayers are not related to geochemical zones or 1ithology. Illite is present in all but one sample and occurs in uniformly low amounts. Total clay-mineral content does not vary systematically within sandstone of different geochemical setting.

\section{Lamprecht deposit}

Montmorillonite, detected in each sample, is commonly but not exclusively the dominant clay mineral in samples from the Oakville Sandstone (table 2). Many samples (49 of 62 ) contain montmorillonite with various proportions of ilite interlayers. As with the mixed-layer clays of the Benavides deposit, those of the Lamprecht bear no pattern relative to geochemical zone or 11thology

The major control on montmorillonite abundance is lithologic: The proportion of montmorillonite relative to other clay minerals is high in sandstone and low in mudstone. This relationship is shown on figure 3 , in which the weight percent of montmorillonite in the clay-mineral population is plotted against the weight percent of clay in the whole sample. Conversely, illite is commonly more abundant than montmorillonite in mudstone (table 2, 


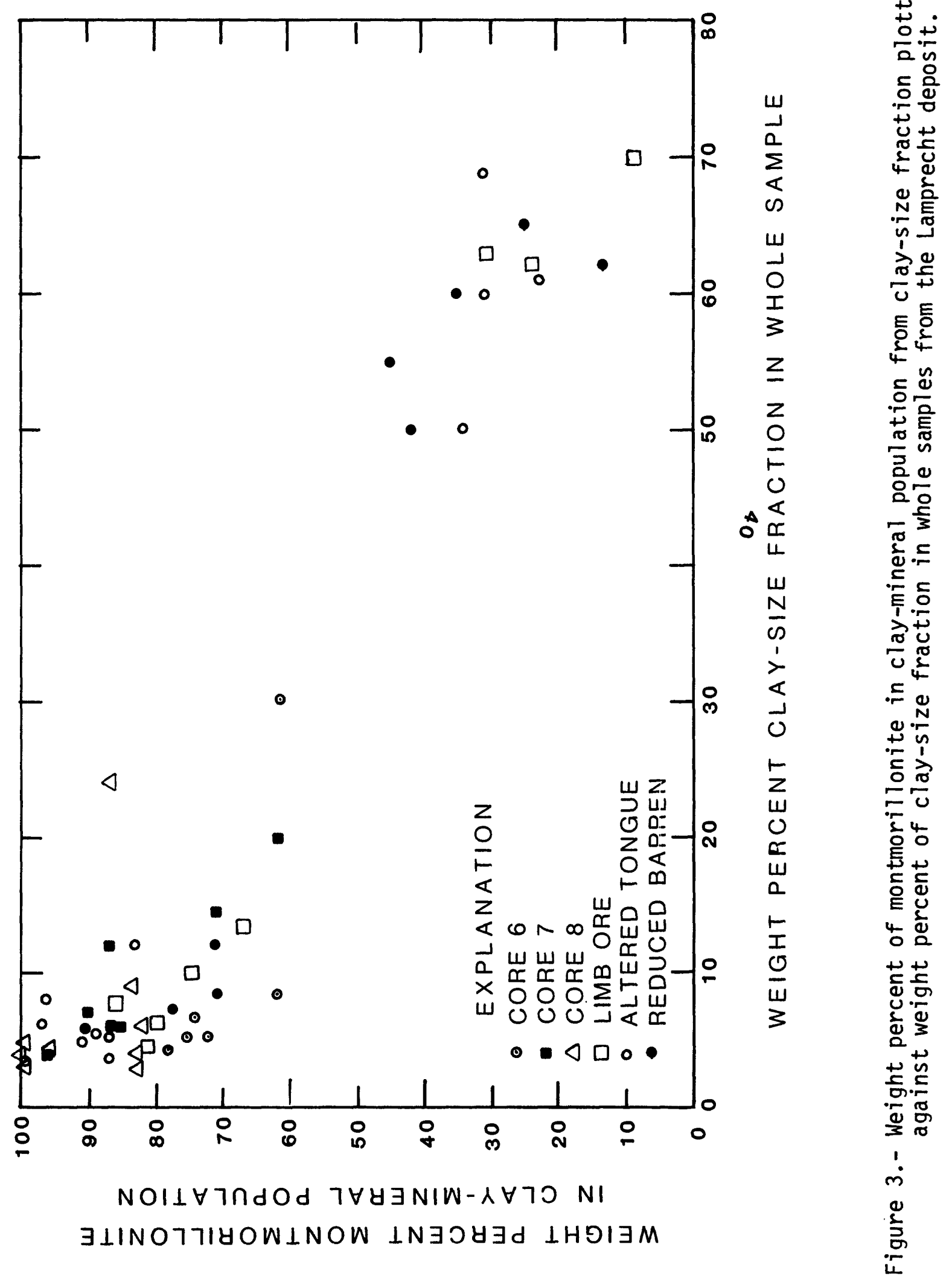


fig. 4). These relationships are evident also in data obtained from unfractionated whole samples (table 3 ).

Kaolinite was detected in the majority of samples (38 of 62 ), but, for the most part, in very small amounts (table 2). Kaolinite was absent in most mudstone samples (10 of 12 ). There is no unambiguous relationship between geochemical zone and the presence and (or) amount of kaolinite. Although kaolinite occurs in a greater proportion of samples in the limb ore and downdip from the roll front (30 of 41) than in unmineralized rock updip from the roll ( 8 of 21 ), this distribution pattern is related partly to lithology in that more mudstone samples were obtained from the unmineralized zone updip from the roll than from elsewhere in the host.

Chlorite, in trace amounts, was detected in only two samples (table 2). Both samples are from the altered tongue, one in a sample rich in clay-size particles, the other in a sample nearly devoid of clay-size particles.

Daniels and others (1977), in a study of the Lamprecht deposit, concluded that high montmorillonite content correlated with high uranium content. Our analysis of the same raw X-ray data used by Daniels and others (1977) shows no such correlation. In fact. mineralized sandstone in core 6 at the nose of the uranium roll contains a smaller proportion of montmorillonite than do most other samples of sandstone (fig. 3). These same samples appear to contain a larger proportion of illite than do other samples of sandstone (fig. 4). In addition, samples of mudstone in $11 \mathrm{mb}$ ore contain relatively small amounts of montmorillonite as do other unmineralized mudstones. These conclusions hold upon inspection of figure 5, in which $\mathrm{U}_{3} \mathrm{O}_{8}$ content is plotted against the ratio of montmorillonite to all clay minerals present in each sample. Some samples that have relatively little montmorillonite (less than 40 percent of all clay minerals) contain high values of $\mathrm{U}_{3}{ }^{0} 8$, and, conversely, some samples 


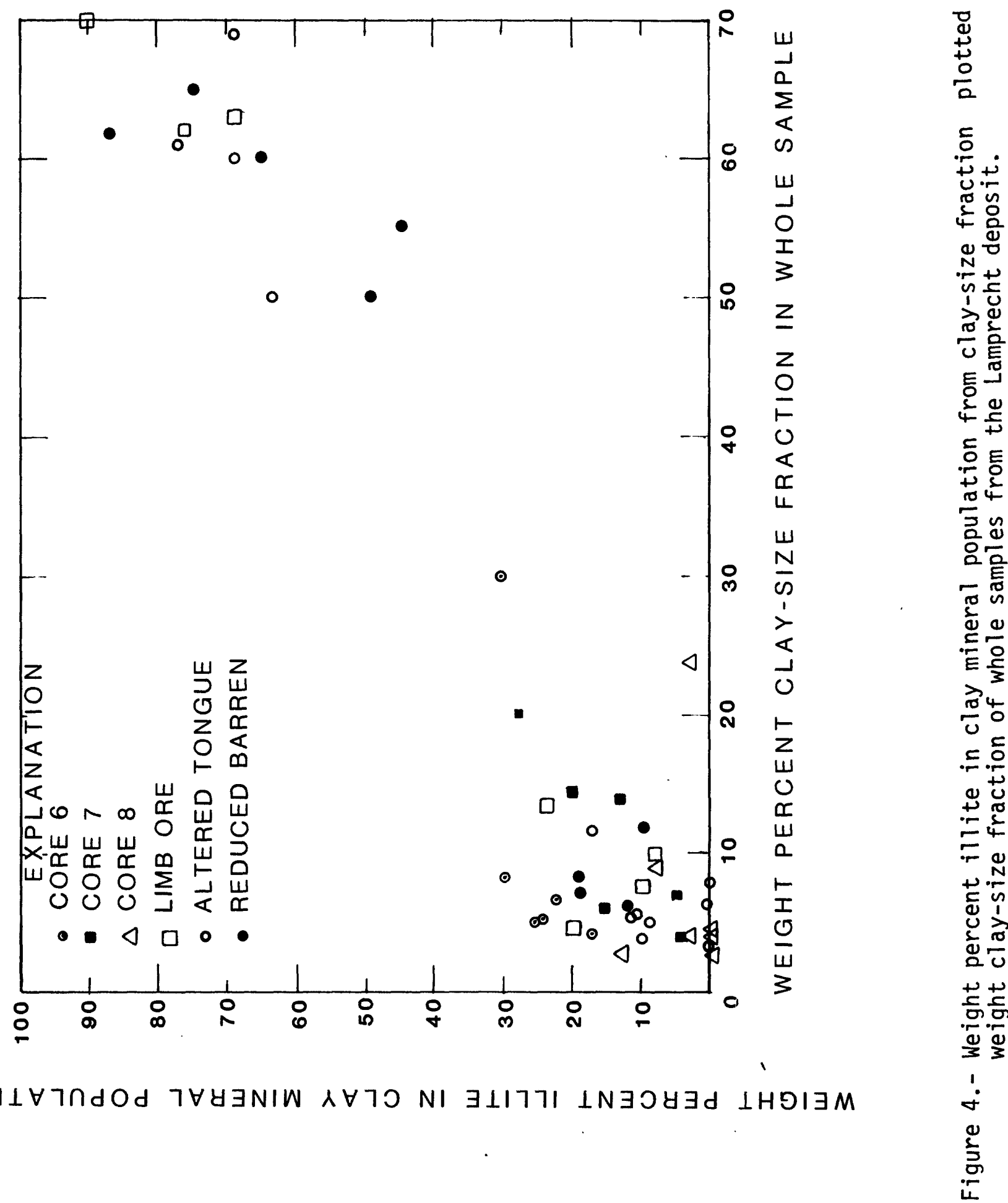


Table 3.--Average proportions of montmorillonite and illite to clay-mineral population in whole samples (weight percent)

from the Lamprecht deposit

$[\mathrm{N}$, number of samples]

\begin{tabular}{|c|c|c|c|c|c|c|}
\hline \multirow[b]{2}{*}{$\begin{array}{l}\text { Lithic } \\
\text { type }\end{array}$} & \multirow[b]{2}{*}{ Geochemical zone } & \multirow[b]{2}{*}{$\mathrm{N}$} & \multicolumn{2}{|c|}{ Montmorillonite } & \multicolumn{2}{|c|}{ Illite } \\
\hline & & & Mean & $\begin{array}{l}\text { Standard } \\
\text { deviation }\end{array}$ & Mean & $\begin{array}{l}\text { Standard } \\
\text { deviation }\end{array}$ \\
\hline \multirow[t]{3}{*}{ Sandstone } & Altered tongue & 8 & 66 & 25 & 23 & 16 \\
\hline & Reduced barren & 22 & 58 & 17 & 23 & 9 \\
\hline & Mineralized & 20 & 57 & 19 & 26 & 9 \\
\hline \multirow[t]{3}{*}{ Mudstone } & Altered tongue & 4 & 30 & 5 & 70 & 5 \\
\hline & Reduced barren & 5 & 32 & 11 & 62 & 18 \\
\hline & Mineralized & 3 & 28 & 13 & 72 & 13 \\
\hline
\end{tabular}




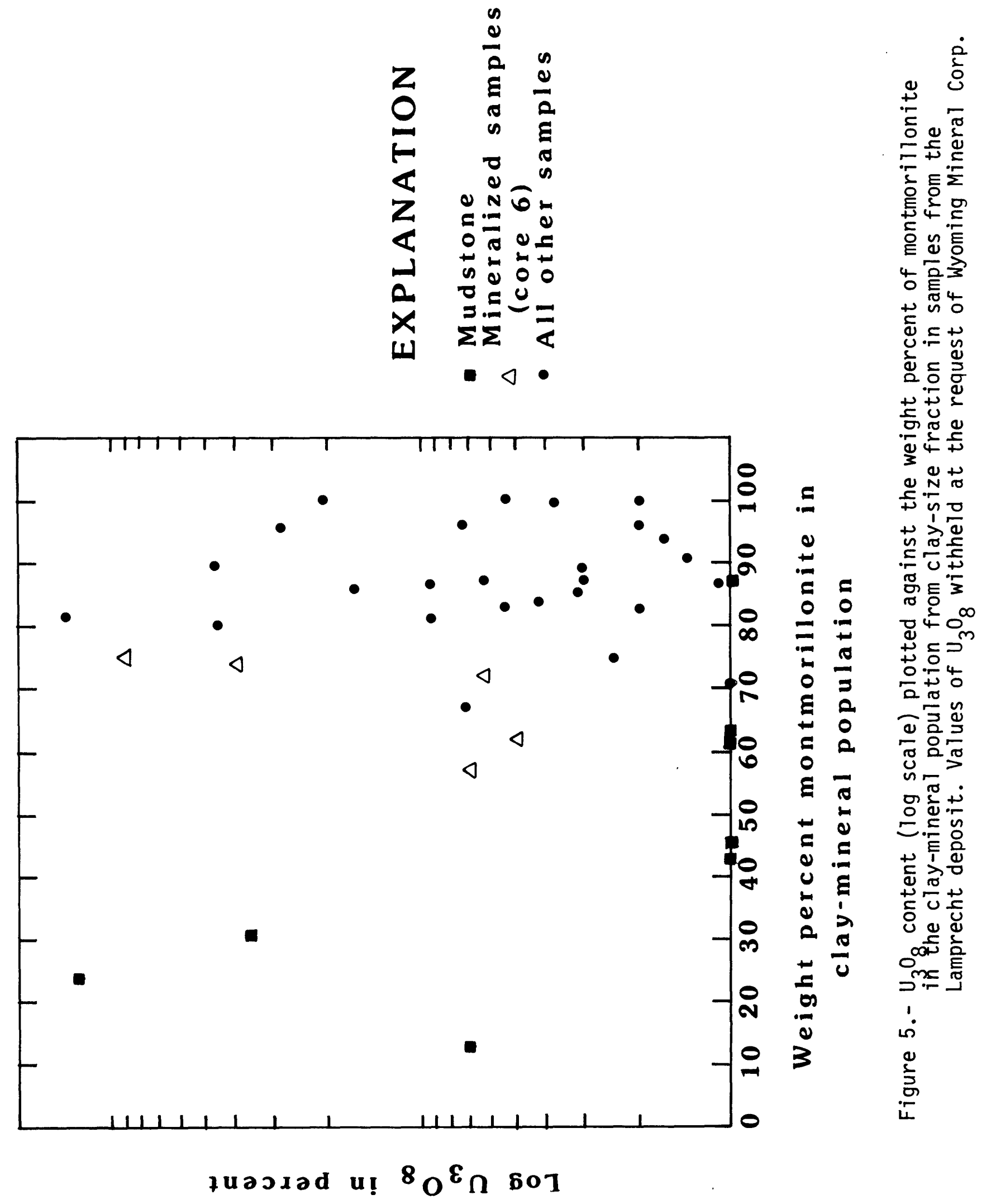


containing high amounts of montmorillonite to all clay minerals contain low amounts of $\mathrm{U}_{3} \mathrm{O}_{8}$

\section{Discussion}

Distribution of montmorillonite in the host rock for the Benavides deposit is unrelated to mineralization. Most of the montmorillonite probably formed by the diagenetic argillization of volcanic ash, detrital montmorillonite clay clasts and clay deposited from descending ground waters are other possible sources. The dominance of montmorillonite relative to 111ite in the mudstones suggests also that the mudstones were initially laden with abundant volcanic ash which altered later to montmorillonite.

Galloway and Kaiser (1979) examined textural relationships among montmorillonite and other detrital and authigenic constituents in the Benavides deposit and concluded that, for the most part, montmorillonite predated mineralization, and that in the ore zone, montmorillonite served as a locus for uranium concentration by adsorption. Additionally, Galloway (1977), Ga1loway and others (1979), and McBride and others (1968) found an abundance of montmorillonite and an absence of chlorite in samples from the Catahoula elsewhere in the Texas Gulf Coastal Plain. Galloway (1977) did not report illite in any samples and found pedogenic and early diagenetic kaolinite in some samples.

As in sandstone of the Catahoula Tuff, montmorillonite is the dominant clay mineral in sandstone of the Oakville Sandstone at the Lamprecht deposit. However, illite is present in somewhat greater amounts (relative to other clays) in sandstone of the Lamprecht than in that of the Benavides deposit. Much of the montmorillonite probably formed by the diagenetic alteration of volcanic detritus, and the illite was probably introduced as a detrital component. 
As noted above, samples of mineralized sandstone in core 6 contain slightly less montmorillonite relative to all clay minerals than do most other samples of sandstone, including mineralized sandstone in cores 7 and 8 . We considered the possibility that this relationship resulted from depletion of montmorillonite under conditions related to the presence of uranium or during mineralization. Depletion of montmorillonite in core 6 , if it occurred, probably did not take place long after mineralization under conditions related to the presence of uranium, Inasmuch as mineralized samples from cores 7 and 8 contain about as much uranium as do samples from core 6. Destruction of montmorillonite at the nose of the present roll front during mineralization under conditions of low $\mathrm{pH}$ (resulting from oxidation of pre-existing $\mathrm{FeS}_{2}$ minerals by the oxygenated uranium-bearing solutions) is also unlikely in view of the observation that montmorillonite is relatively abundant in the altered tongue (table 2) through which the ore roll migrated. Furthermore, depletion of montmorillonite is not characteristic of the mineralized upper and lower limbs of cores updip from core 6. Geochemical conditions during formation of $11 \mathrm{mb}$ ore must have been broadly similar to those at the nose of the roll near core 6. We conclude, therefore, that the distribution of montmorillonite in the Lamprecht cannot be related confidently to mineralization processes or to the present distribution of ore.

The deposits discussed in this report and those in the Jurassic Morrison Formation and in the Eocene sandstones of the Wyoming basins reported by others to be characterized by zonation of clay minerals, particularly chlorite, differ in several ways. First, the sources for and compositions of host rocks for the deposits in the Morrison and in the Eocene of the Wyoming basins and for the Benavides and Lamprecht deposits are dissimilar in several respects. Sandstones of the Wyoming basins and of the Morrison Formation in 
the area of the Grants mineral belt are commonly arkosic, having been derived primarily from Precambrian crystalline rocks. In contrast, quartz-rich sandstones, derived from distant, acidic volcanic source terrain and reworked from older sedimentary rocks are characteristic of the Catahoula and Oakville hosts. One might expect, therefore, that the diversity of the clay-mineral population in the Morrison and in the sandstones of the Wyoming basins reflects partly an original abundance of unstable detrital minerals and that the relative simplicity of the clay-mineral population in the Lamprecht and Benavides deposits reflects partly the relatively simple compositions of the Catahoula Tuff and Oakville Sandstone. Nevertheless, biotite, the alteration of which may result in chlorite in many near-surface environments (Markos, 1977), is present in the Morrison Formation (Cadigan, 1967), the sandstones in Wyoming studied by Files (1970), and the Catahoula Tuff.

Second, and more importantly, mineralization processes in the Morrison differed greatly from those processes in the Oakville and Catahoula. A major control on the localization of the primary (or tabular) ore bodies in the Morrison Formation was the presence of organic matter (suggested to be humic acids; see for example, Brookins, 1975). Interaction of these organic materials with detrital or early diagenetic montmorillonite may have been responsible for the observed concentrations of chlorite in ore zones in the Morrison (Brookins, 1975).

The ore bodies in Wyoming studied by Files (1970) and those in Texas discussed in this report have roll shapes and probably formed under similar hydrologic mechanisms. However, host rocks for the deposits in Wyoming contain concentrations of organic matter localized near the redox boundary (Files, 1970) which may have exerted important controls in geochemical processes of ore deposition (for example, Rackley, 1972) and which also may have influenced clay-mineral authigenesis as in the Morrison Formation. 
The presence of organic material as carbonaceous trash may have affected the authigenesis of chlorite in part of the Morrison Formation and in the Eocene sandstones of Wyoming in another way. Some types of organic material may be utilized as a substrate by heterotrophic sulfate-reducing bacteria to form pyrite; such metabolic activity increases the $\mathrm{pH}$ of the solution (Goldhaber and Reynolds, 1979). Increased $\mathrm{pH}$ favors chlorite at the expense of kaolinite, montmorillonite, or microcline for constant activity of potassium, magnesium, and silica in the system $\mathrm{HCl}-\mathrm{H}_{2} \mathrm{O}-\mathrm{Al}_{2} \mathrm{O}_{3}-\mathrm{CO}_{2}-\mathrm{K}_{2} \mathrm{O}-$ $\mathrm{MgO}-\mathrm{SiO}_{2}$ (Helgeson and others, 1969). The close textural association of chlorite and biogenic pyrite (indicating a common origin) which has been observed in some other sedimentary rocks (Siever and Kastner, 1972) may reflect these conditions.

Many uranium deposits associated with carbonaceous matter show zonation of authigenic clay minerals (commonly but not universally chlorite). In contrast, the Benavides and Lamprecht deposits are virtually devold of organic matter and show no distribution patterns of clay minerals which can be related to mineralization processes. It is possible that the presence (or absence) of organic material, or at least organically derived acids, may be responsible in part for clay-mineral zonation (or lack of it) in uranium deposits.

\section{Acknowledgments}

We gratefully acknowledge Wyoming Mineral Corp. for supplying samples, for permission to cite the names and locations of the deposits, and for use of company material. 


\section{References}

Adams, S. S., Curtis, H. S., Hafen, P. L., and Salek-Nejad, Hossein, 1978, Interpretation of postdepositional processes related to the formation and destruction of the Jackpile-Paguate uranium deposit, northwest New Mexico: Economic Geology, v. 73, p. 1635-1654.

Brookins, D. G., 1975, Uranium in deposits of the Grants, New Mexico mineral belt: Grand Junction, Colorado, U.S. Energy Research and Development Administration Open-File Report GJBX-16(76), 153 p.

Cadigan, R. A., 1967, Petrology of the Morrison Formation in the Colorado Plateau region: U.S. Geological Survey Professional Paper 556, 113 p. Danie1s, J. J., Scott, J. H., Blackmon, P. D., and Starkey, H. S., 1977, Borehole geophysical investigations in the south Texas uranium district: U.S. Geological Survey Journal of Research, v. 5, p. 343-357. Dickinson, K. A., and Sullivan, M. W., 1976, Geology of the Brysch uranium mine, Karnes County, Texas: U.S. Geological Survey Journal of Research, v. 4, p. 397-404.

Files, F. G., 1970, Geology and alteration associated with Wyoming uranium deposits: Berkeley, University of California Ph.D. thesis, $113 \mathrm{p}$. Galloway, W. E., 1977, Catahoula Formation of the Texas Coastal Plain-Depositional systems, composition, structural development, ground-water flow history, and uranium distribution: Austin, Texas University, Bureau of Economic Geology Report of Investigations 87, 59 p.

Galloway, W. E., Finley, R. J., and Henry, C. D., 1979, South Texas uranium province--geologic perspective: Austin, Texas University, Bureau of Economic Geology, Guideböok 18, 81 p.

Galloway, W. E., and Kaiser, W. R., 1979, Catahoula Formation of the Texas Coastal Plain--origin, geochemical evolution, and characteristics of 
uranium deposits: Austin, Texas University, Bureau of Economic Geology, $139 \mathrm{p} \cdot$

Garrells, R. M., Larsen, E. S., Pommer, A. M., and Coleman, R. G., 1959, Detailed chemical and mineralogic relations in two vanadium-uranium ores: U.S. Geological Survey Professional Paper 320, p. 165-184.

Goldhaber, M. B., and Reynolds, R. L., 1977, Geochemtcal and mineralogical studies of a south Texas roll front uranium deposit: U.S. Geological Survey Open-File Report 77-821, 34 p. 1979, Origin of marcasite and its implications regarding the genesis of roll-type uranium deposits: U.S. Geological Survey Open-File Report 79$1696,40 \mathrm{p}$.

Goldhaber, M. B., Reynolds, R. L., and Rye, R. 0., 1978, Origin of a south Texas roll-type uranium deposit. II. Sulfide petrology and sulfur 1sotope studies: Economic Geology, v. 73, p. 1690-1705. 1979, Formation and resulfidization of a south-Texas roll-type uranium deposit: U.S. Geological Survey Open-File Report 79-1651, 41 p. Granger, H. C., 1962, Clays in the Morrison Formation and their spatial relationship to the uranium deposits at Ambrosia Lake, New Mexico: U.S. Geological Survey Professional Paper 450-D, p. D15-D20.

Granger, H. C., and Warren, C. G., 1974, Zoning in the altered tongue associated with roll-type uranium deposits, in Formation of uranium ore deposits: Vienna, International Atomic Energy Agency, p. 185-200.

Helgeson, H. C., Brown, T. H., and Leeper, R. H., 1969, Handbook of theoretical activity diagrams depicting chemical equilibria in geologic systems Involving an aqueous phase at one atm and $0^{\circ}$ to $300^{\circ} \mathrm{C}$ : San Francisco, Freeman, Cooper and Company, 253 p. 
Markos, G., 1977, Geochemical alteration of plagloclase and biotite in glacial and periglacial deposits: Boulder, Colorado University, unpub. Ph.D. thesis.

McBride, E. F., Lindemann, W. L., and Freeman, P. S., 1968, Lithology and petrology of the Gueydan (Catahoula) Formation in south Texas: Texas University Bureau of Economic Geology Report of Investigations 67, 52 p.

Rackley, R. I., 1972, Environment of Wyoming Tertiary uranium deposits: American Association of Petroleum Geologists Bulletin, v. 56, p. 755-774. Reynolds, R. L., and Goldhaber, M. B., 1978, Origin of a south Texas roll-type uranfum deposit. I. Alteration of iron-titanium oxide minerals: Economic Geology, v. 73, p. 1677-1689.

Siever, Raymond, and Kastner, Miriam, 1972, Shale petrology by electron microprobe: Pyrite-chlorite relations: Journal of Sedimentary Petrology, v. 42, p. 350-355. 